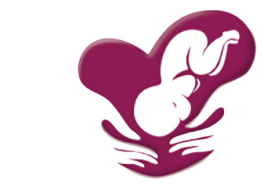

Published By: PERINASIA The Indonesian Society of Perinatology

\section{The impact of the Covid-19 pandemic on successful breastfeeding: analysis of the impact of Covid-19 on routine visits and breastfeeding plans at Kasih Medika}

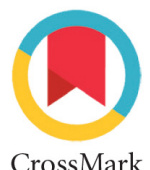

CrossMark

\author{
Cokorda Istri Mirayani Pemayun ${ }^{1}$, I Nyoman Hariyasa Sanjaya ${ }^{2 *}$, \\ Firsta Sesarina Mintariani ${ }^{3}$, Made Diah Vendita Sakuntari ${ }^{3}$, Ni Nyoman Dewi Purwanti ${ }^{3}$, \\ Ni Putu Nining Gianni ${ }^{3}$, Ni Luh Made Diah Mas Cahyani Putri ${ }^{3}$, \\ Ni Luh Made Dwi Laxmi Satriani ${ }^{3}$, Ni Komang Anik Pirgantari ${ }^{3}$, \\ Ni Luh Putu Yulia Padmawati ${ }^{3}$, Anak Agung Wahyu Putri Agustini ${ }^{3}$
}

\section{ABSTRACT}

'Outpatient Clinic Sanglah General Hospital Denpasar, Bali, Indonesia ${ }^{2}$ Obstetric and Gynecologic Department Medical Faculty, Universitas Udayana Sanglah General Hospital, Denpasar, Bali, Indonesia

${ }^{3}$ Kasih Medika Pregnancy School, Denpasar, Bali, Indonesia research aimed to evaluate the impact of COVID-19 pandemic with the routine visits and breastfeeding plan.
Introduction: All human worldwide had a risk infected by a severe acute respiratory syndrome-coronavirus-2 (SARSCoV-2), including pregnant woman. Nowadays, SARS-CoV-2 transmission is still not fully understood. Thus, this situation created anxiety particularly for mothers that planned to breast-feed their baby and did their routine hospital visit. Thus this

Methods: This study was carried out with cross sectional observational study at Kasih Medika Hospital. The routine visits were conducted on the 5th-10th of August 2020. This study used a questionnaire instrument with samples of pregnant and postpartum mothers. The inclusion criteria of the sample were all pregnant women and post-partum that registered in Kasih Medika Hospital, complete questionnaire data filled in. The exclusion criteria were the patient agreed to be the research sample. All of the data was analyzed descriptively by using SPSS 25 and was presented by frequency.

Results: All of the patients felt anxious with different stages of anxiety. COVID-19 affects 18\% of patients who reduce their routine visits to Kasih Medika, while $82 \%$ keep visiting as scheduled. The COVID-19 pandemic had an insignificant effect on breastfeeding plans. This can be seen from only $27 \%$ of all respondents who are afraid of their breastfeeding plans. However, in the primigravida population, $45.45 \%$ of respondents were worried about their breastfeeding plan. Although in multigravida and post-partum, it was found that $90.90 \%$ were not afraid of their breastfeeding plans during the COVID-19 period. Conclusion: Our research established that COVID-19 reduces pregnant women's attendance to hospital, and patient primigravida was mainly afraid to do breastfeeding plans rather than multigravida patients. In contrast, mostly multigravida.

Keywords: Breastfeeding plan, COVID-19, hospital visit, pregnant woman, post-partum

Cite This Article: Pemayun, C.I.M., Sanjaya, I.N.H., Mintariani, F.S., Sakuntari, D.V., Purwanti, N.N.D., Gianni, N.P.N., Putri, N.L.M.D.M.C., Satriani, N.L.M.D.L., Pirgantari, N.K.A., Padmawati, N.L.P.Y., Agustuni, A.A.W.P. 2021. The impact of the Covid-19 pandemic on successful breastfeeding: analysis of the impact of Covid-19 on routine visits and breastfeeding plans at Kasih Medika. Indonesian Society Of Perinatology 2(2): 32-35. D0I: 10.51559/inajperinatol.v2i2.14

Received: 2021-07-20

Accepted: 2021-08-29

Published: 2021-09-11

\section{INTRODUCTION}

The COVID-2019 epidemic, caused by extreme intense respiratory disorder coronavirus, was first identified in Hubei Area China in December 2019 and has in this way spread universally, putting broad weight on wellbeing frameworks and posturing a major public health challenge around the world. ${ }^{1}$ On March 11, 2020, the World Health Organization (WHO) announced the widespread outbreak. ${ }^{2}$ Approximately COVID-19 or its impacts on the common populace, and indeed less was known approximately how it might influence specific populaces such as pregnant ladies, newborn babies, or children. Simple spread to other individuals with air due to its transmission by droplets, coughing, wheezing, and others. It moreover can contaminate the body by attaching to our conjunctiva adjacent to through the respiratory tract. Clings to a few stuff as of now proven by a few studies. ${ }^{3}$

A research study confirmed that $78.95 \%$ of medical staff had positive COVID-19, and the rest were non-medical staff $(21.05 \%){ }^{4}$ It showed COVID-19 transmission in hospitals is more accessible than in other places. Another study reported that children of all ages are sensitive to COVID-19, nevertheless no association COVID-19 related gender. ${ }^{5}$ Moreover, reports have been published on 38 pregnant women with COVID-19 from 
China.$^{6-9}$ A retrospective observational study was conducted in New York that observed pregnant women infected by a coronavirus in the third trimester. After that, twenty-one neonates were assessed for COVID-19 after birth. SARS-CoV-2 RT-PCR test results were negative in $100 \%$ of the neonates. Moreno,2020 Whereas different finding was found in a meta-analysis study that stated from 936 neonates from mothers with COVID19, 27 neonates had a positive result for severe acute respiratory disorder coronavirus (95\% CI: 2.2-4.3) for vertical transmission. ${ }^{10}$ In the interim, there's still a deficient understanding of COVID-19 transmission. ${ }^{1-3}$

This condition will impact the hospital visits by the pregnant women and also the breastfeeding plan. However, WHO already informs mothers with COVID-19 who can breastfeed their babies as long as they take appropriate precautions. ${ }^{6,11}$ Thus, this research aimed to analyze the impact of COVID-19 on routine visits and breastfeeding plans at Kasih Medika.

\section{METHODS}

This study was carried out with cross sectional observational study at Kasih Medika Hospital. The routine visits were conducted on the $5^{\text {th }}-10^{\text {th }}$ of August 2020 . This study used a questionnaire instrument with samples of pregnant and postpartum mothers. The sample's inclusion criteria were all pregnant women and post-partum that registered in Kasih Medika Hospital, complete questionnaire data filled in. The exclusion criteria were the patient agreed to be the research sample. All of the data was analyzed descriptively by using SPSS 25 and was presented by frequency.

\section{RESULTS}

According to our findings, the COVID-19 pandemic had a psychological effect on Kasih Medika patients, which can be seen from the results of all respondents. All of the patients felt anxious with different stages of anxiety. COVID-19 affects $18 \%$ of patients who reduce their routine visits to Kasih Medika, while $82 \%$ keep visiting as scheduled. Some patients carry out activity restrictions to prevent transmission of the disease, $86 \%$ of respondents restricted their activities during the COVID-19 pandemic. The COVID-19 had an insignificant effect on breastfeeding plans. This can be seen from only $27 \%$ of all respondents who are afraid of their breastfeeding plans. However, in the primigravida population, $45.45 \%$ of respondents were afraid of their breastfeeding plan. In Multigravida and post-partum, it was found that $90.90 \%$ were not afraid of their breastfeeding plans during the COVID-19 period. However, in the Primigravida population, $45.45 \%$ of respondents are feeling afraid about their breastfeeding plans. Multigravida and post-partum respondents found that $90.90 \%$ were not afraid about their breastfeeding plans during the Covid-19 period. Specific information could be seen in Figure 1.

\section{DISCUSSION}

Widespread COVID-19 affects in every single perspective, one of them are compliance level of hospital visits of pregnant women, additionally

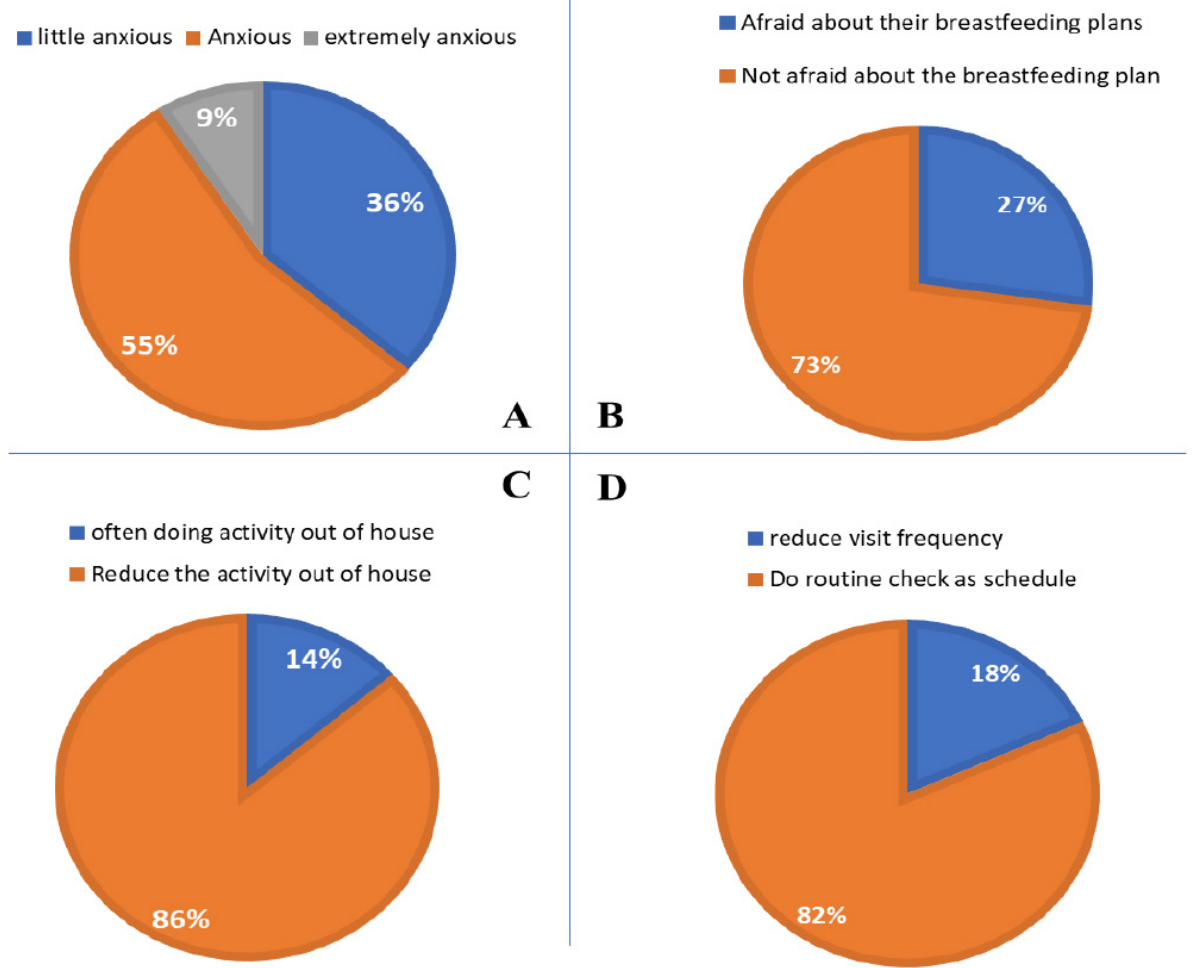

Figure 1. Respond to the postpartum and pregnant woman patients in this pandemic breastfeeding aspect. Easy to spread by droplet transmission ended up the reason the infections were truly infectious. A direct or indirect contact (environment and objects touched) with infected people could transmit this virus. ${ }^{3}$ A research study established from 19 confirmed Covid-19 cases, 15 of them were medical staff $(78.95 \%)$, and the rest were nonmedical staff $(21.05 \%)$. The risk factors of transmission were direct contact with affirmed Covid-19 quiet and ignored health convention. ${ }^{4}$ Those all become a reason a few people, especially pregnant women, restricted their scheduled visits to the hospital. According to our findings, $18 \%$ of pregnant ladies who diminish their activity come to the hospital to do antenatal care. Similar to our finding, Nisma et al. ponder found that widespread essentially affects the compliance level of antenatal care visits. It reported one of the reasons was information level $(\mathrm{p}=0.00) .^{12}$ In addition, a study in Pekanbaru reported from 40 samples, $47.5 \%$ did not do antenatal care. It is mean that the pregnant women either limit their schedule to a 
healing center or did not come to the hospital due to COVID-19 infection. ${ }^{13}$

In addition, this condition too impacts maternal psychology. Pregnant women and new mothers are more likely to involve mental illness than non-pregnant people. Studies in Indica, China, Italy about postpartum and intrapartum with mental illness such as anxiety, and depression had a correlation with COVID-19. They were afraid to transmit the virus in any way, such as vertical transmission. In addition, restricted accessibility of antenatal care assets, and need for social support related COVID-19 infection were happening too. These encounters, making a source of a push for pregnant and postpartum women without COVID19. Also, based on a small case series, proposed a positive relationship between both clinically relevant maternal anxiety and depression and the amounts of COVID-19-related deaths within the populace. Linear with a few previous studies, our finding appeared that all of the patients were anxious due to COVID-19, especially when coming to the hospital. ${ }^{14}$

Another viewpoint that might affect the mother in this pandemic era was the breastfeeding plan. Despite the fact that the WHO already suggests that the mothers keep lactating during the pandemic, pregnant women are still anxious that COVID-19 can infect their infant during lactating. It already reports in a United Kingdom study that found there was inadequate feeding support. In the US, changing the breastfeeding plan was conducted in this pandemic era. In Turkey, a higher rate of formula milk instead of breastfeeding. ${ }^{15}$ Comparable with our finding that COVID-19 burden affects the breastfeeding plan. Several studies illustrated that continued, frequent breastfeeding is related to greater straight development and further protects child health by delaying maternal fertility postpartum and diminishing the child's risk of morbidity and mortality. ${ }^{16}$ Breastfeeding can strengthen the emotional bond between the mother and the baby. ${ }^{17}$ The current WHO recommendations showed that moms should give exclusive breastfeeding to their babies during the first six months of life. ${ }^{18}$ Women with confirmed or suspected
COVID-19 disease are empowered to breastfeed in nonattendance of other restrictions. However, precautions ought to be taken to minimize potential issues. Room sharing and uninterrupted motherinfant proximity are suggested as critical factors for building up great breastfeeding for mothers with COVID-19, providing that specific and suitable respiratory and skin hygiene measures are taken. If moms are incapable of breastfeeding owing to severe wellbeing conditions caused by COVID-19, they ought to get back from competent health care experts. They may be advised to breastfeed their baby through a secure elective strategy, such as breastfeeding or relactation. If that's not conceivable, other options can be considered, such as the utilize of certified donor milk bank services designed to ensure the incoming drain supply by rigorous screening criteria for milk donors. ${ }^{16-18}$

\section{CONCLUSION}

COVID19 brings an impact on pregnant and postpartum women, especially for their plans to breastfeeding. Breastfeeding during The COVID-19 Pandemic has more benefits than disadvantages. Despite WHO already informing that, several mothers, still afraid to do breastfeeding plans. Our research established that COVID-19 reduces pregnant women's attendance to hospital, and patient primigravida was mostly afraid to do breastfeeding plans rather than multigravida patients. In contrast, mostly multigravida.

\section{DISCLOSURE}

\section{Conflict of interest \\ None}

\section{Ethical approval}

This research has been approved by the ethics commission of Udayana University with no Ethical Clearance

\section{Funding}

This research is self-funded

\section{Author's contribution}

All authors contributed equally in compiling this research article

\section{REFERENCES}

1. Fauci AS, Lane HC, Redfield RR. Covid-19 - Navigating the Uncharted. N Engl J Med. 2020;382(13):1268-9. Available from: http:// dx.doi.org/10.1056/nejme2002387

2. World Health Organization. Rolling updates on coronavirus disease (COVID-19) [Internet]. 2020. Available from: https://www.who.int/ emergencies/diseases/novel-coronavirus-2019/ events-as-they-happen

3. World Health Organization. Modes of transmission of virus causing COVID-19: implications for IPC precaution recommendations [Internet]. 2021. Available from: https://www.who.int/news-room/ commentaries/detail/modes-of-transmissionof-virus-causing-covid-19-implications-foripc-precaution-recommendations

4. Ulfah S, Candi C, Darmawan ES. Risk Factors of Covid-19 Transmission. 7th Int Conf Public Heal. 2020;(021):18-9. Available from: http:// theicph.com/id_ID/2020/12/04/risk-factorsof-covid-19-transmission-between-hospitalemployees/

5. Eastin C, Eastin T. Epidemiological characteristics of 2143 pediatric patients with 2019 coronavirus disease in China. J Emerg Med. 2020;58(4):712-3. Available from: http:// dx.doi.org/10.1016/j.jemermed.2020.04.006

6. Chen H, Guo J, Wang C, Luo F, Yu X, Zhang $\mathrm{W}$, et al. Clinical characteristics and intrauterine vertical transmission potential of COVID-19 infection in nine pregnant women: a retrospective review of medical records. Lancet. 2020;395(10226):809-15. Available from: $\quad$ http://dx.doi.org/10.1016/s01406736(20)30360-3

7. Zhu H, Wang L, Fang C, Peng S, Zhang L, Chang $\mathrm{G}$, et al. Clinical analysis of 10 neonates born to mothers with 2019-nCoV pneumonia. Transl Pediatr. 2020;9(1):51-60. Available from: http://dx.doi.org/10.21037/tp.2020.02.06

8. Wang X, Zhou Z, Zhang J, Zhu F, Tang Y, Shen X. A Case of 2019 Novel Coronavirus in a Pregnant Woman With Preterm Delivery. Clin Infect Dis. 2020;71(15):844-6. Available from: http://dx.doi.org/10.1093/cid/ciaa200

9. Zhang L, Jiang Y, Wei M, Cheng BH, Zhou XC, $\mathrm{Li}$ J, et al. [Analysis of the pregnancy outcomes in pregnant women with COVID-19 in Hubei Province]. Zhonghua Fu Chan Ke Za Zhi. 2020;55(3):166-71.

10. Kotlyar AM, Grechukhina O, Chen A, Popkhadze S, Grimshaw A, Tal O, et al. Vertical transmission of coronavirus disease 2019: a systematic review and meta-analysis. Am J Obstet Gynecol. 2020/07/31. 2021;224(1):3553.e3. Available from: https://pubmed.ncbi. nlm.nih.gov/32739398

11. Rebhan B, Kohlhuber M, Schwegler U, Fromme H, Abou-Dakn M, Koletzko B V. Breastfeeding duration and exclusivity associated with infants' health and growth: data from a prospective cohort study in Bavaria, Germany. Acta Paediatr. 2009;98(6):974-80. Available from: http://dx.doi.org/10.1111/ j.1651-2227.2009.01281.x 
12. Nisma, Sundari, Gobel FA. Pengaruh Pengetahuan dan Sikap Terhadap Kepatuhan Ibu Hamil Dalam Pemeriksaan ANC Pada Masa Pandemi di Poskesdes Bungadidi Kec. Tana Lili. J Muslim Community Heal. 2021;2(1):108-20. Available from: https://pasca-umi.ac.id/index. php/imch/article/view/491

13. Refiani D, Dewi YI, Utami S. Gambaran Perilaku Ibu Hamil dalam Melakukan Antenatal Care saat Pandemi Covid-19 di Puskesmas Rawat Inap Sidomulyo Kota Pekanbaru. Heal Inf J Penelit. 2021;13(2).

14. Kotlar B, Gerson E, Petrillo S, Langer A, Tiemeier $\mathrm{H}$. The impact of the COVID-19 pandemic on maternal and perinatal health: a scoping review [Internet]. Vol. 18, Reproductive Health. BioMed Central; 2021. Available from: https://doi.org/10.1186/s12978-021-01070-6

15. Pacheco F, Sobral M, Guiomar R, de la TorreLuque A, Caparros-Gonzalez RA, Ganho-ávila A. Breastfeeding during covid-19: A narrative review of the psychological impact on mothers. Behav Sci (Basel). 2021;11(3).

16. World Health Organization. Continued breastfeeding for healthy growth and development of children [Internet]. e-Library of Evidence for Nutrition Actions (eLENA). 2019. Available from: https://www.who.int/ elena/titles/continued breastfeeding/en/
17. Kementerian Kesehatan RI. Manfaat ASI Eksklusif untuk Ibu dan Bayi [Internet]. 2018. Available from: https://promkes.kemkes.go.id/ manfaat-asi-eksklusif-untuk-ibu-dan-bayi

18. World Health Organization. A guide to WHO's guidance on COVID-19 [Internet]. 2020. Available from: https://www.who.int/newsroom/feature-stories/detail/a-guide-to-who-sguidance

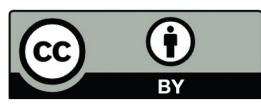

This work is licensed under a Creative Commons Attribution 